\title{
Heat unit requirement and yield of wheat (Triticum aestivum L.) varieties under different growing environment in mid hill conditions of Himachal Pradesh
}

\author{
RANU PATHANIA ${ }^{1}$, RAJENDRA PRASAD ${ }^{2}$, RANBIR SINGH RANA ${ }^{2}$ and S. K. MISHRA ${ }^{3}$ \\ ${ }^{1}$ Department of Agriculture, Himachal Pradesh \\ ${ }^{2}$ Department of Agronomy, Forages and Grassland Management, CSKHPKV, Palampur, Himachal Pradesh \\ ${ }^{3}$ Punjab Agricultural University, Regional Research Station, Faridkot, Punjab \\ *Corresponding author: ranu44raone@gmail.com
}

\begin{abstract}
A field experiment was conducted during rabi seasons of 2015-16 and 2016-17 to study the accumulated growing degree days (GDD), helio-thermal unit (HTU), photo-thermal unit (PTU), heat use efficiencies (HUE) at different phenological stages and performance of wheat (Triticum aestivum L.) varieties grown under different sowing dates. Results of present study revealed that the crop sown on $20^{\text {th }}$ October required maximum calendar days, growing degree days, photo-thermal unit and helio-thermal unit for tillering, flowering, earing and maturity which was significantly reduced with subsequent delay in sowing time. The grain yield recorded in $20^{\text {th }}$ November $\left(4065 \mathrm{kgha}^{-1}\right)$ was statistically at par with $5^{\text {th }}$ November yield $\left(3863 \mathrm{kgha}^{-1}\right)$. The significant reduction in grain yield on varieties was recorded when sowing was delayed beyond $20^{\text {th }}$ November. Among the varieties 'VL-907' produced highest grain yield $\left(3771 \mathrm{kgha}^{-1}\right)$ which was statistically on par with 'VL-829' $\left(3726 \mathrm{kgha}^{-1}\right)$. The early and timely sown wheat variety like VL-829 and VL-907 took highest calendar days, GDD, HTU and PTU for earing and maturity. The variety 'VL-907' recorded the highest grain yield (4196 and $4168 \mathrm{kgha}^{-1}$ ) at $5^{\text {th }}$ and $20^{\text {th }}$ November sowing as compared to all other sowing dates.
\end{abstract}

Key words: Wheat, GDD, PTU, HTU, PTI, Grain yield

Wheat (Triticum aestivum L.) an important, widely adapted rabi crop grown from temperate irrigated to dry and high rainfall areas ranging from warm humid to dry cold environments of India. It occupies approximately 30.6 million hectares area with 98.5 million tonnes wheat production in India (FAO 2017). Cool weather during vegetative period and warm weather during maturity are ideal for wheat. Changes in seasonal temperature affect the productivity through the changes in phenological development of the crop. Date of sowing is most important factors that govern the phenological development of the crop and also influence the conversion of biomass into economic yield. Being a temperature sensitive crop, late sown wheat crop is sometimes exposed to low temperature at the time of establishment and often to high temperature during reproductive phase that accelerate the maturity predominantly in North Indian conditions. This not only inhibits the crop growth, but also affects the yield and yield components of wheat. Therefore, the optimization of sowing time is an important parameter to attain maximum yield and efficient conversion of biological yield into economic yield. Generally, normal sowing has longer growth duration which consequently supports high biomass accumulation as compared to late sowing and henceforth manifested in higher grain and biological yield (Singh and Pal, 2003). Influence of temperature on phenology and yield of crop plants can be studied under field condition through accumulated heat units system (Bishnoi et al. 1996). Though accumulation of degree-days for each development stage is relatively constant and independent on sowing date, but it considerably vary among the varieties. Under North Indian condition, the maturity of wheat hastened due to gradual rise in ambient temperature under delayed planting (Hari Ram et al. 2012; Bist et al. 2019). Hence, it becomes imperative to have knowledge of exact duration of phenological stages in a particular crop-growing environment and their impact on yield of crop. Growing of suitable variety at an appropriate time is essential for ensuring optimum productivity. Being a thermosensitive crop, choice of suitable variety for different sowing windows further gets prime importance. Therefore, an experiment was planned to determine the phenology and heat unit requirement of promising wheat varieties under different growing environments in mid hill conditions of Himachal Pradesh

\section{MATERIALS AND METHODS}

A field investigation was conducted at the experimental farm 
of CSK HP University, Palampur during the rabi seasons of 2014-15 and 2015-16. The experiment was conducted in split plot design with five dates of sowing $\left(20^{\text {th }}\right.$ October, $5^{\text {th }}$ November, $20^{\text {th }}$ November, $5^{\text {th }}$ December and $20^{\text {th }}$ December) in main plots and four varieties of wheat (viz., HS-490, VL829, VL-892 and VL-907) in sub-plots with three replications. Wheat crop was sown with the row spacing of $22.5 \mathrm{~cm}$ as per treatments. Two irrigations (50 $\mathrm{mm}$ water in each irrigation) were applied at two critical phenological stages. The crop was fertilized with $120 \mathrm{~kg} \mathrm{~N}, 60 \mathrm{~kg} \mathrm{P}_{2} \mathrm{O}_{5}$ and $40 \mathrm{~kg} \mathrm{~K}_{2} \mathrm{O}$. Out of which, $1 / 3^{\text {rd }} \mathrm{N}$ and full dose of $\mathrm{P}_{2} \mathrm{O}_{5}$ and $\mathrm{K}_{2} \mathrm{O}$ were applied as basal dose at the time of sowing by broadcasting method. The remaining $2 / 3^{\text {rd }}$ dose of $\mathrm{N}$ were given in two equal splits at CRI and late tillering stages. Meteorological data viz., rainfall $(\mathrm{mm})$, maximum and minimum relative humidity (\%), maximum and minimum temperature $\left({ }^{\circ} \mathrm{C}\right)$, duration of bright sunshine (hours), wind speed $\left(\mathrm{kmh}^{-1}\right)$ etc. were recorded from Agrometeorological observatory, CSK HPKV, Palampur. Following agro-meteorological indices were computed using the daily meteorological data.

$\operatorname{GDD}\left({ }^{\circ} \mathrm{C}\right.$ day $)=\sum(\operatorname{Tmax}+\operatorname{Tmin}) / 2-4.5($ base temperature $)$

$\operatorname{PTU}\left({ }^{\circ} \mathrm{C}\right.$ day hour $)=\sum(\mathrm{GDD} \times$ day length $)$

$\mathrm{HTU}\left({ }^{\circ} \mathrm{C}\right.$ day hour $)=\sum(\mathrm{GDD} \times$ actual bright sun shine hours $)$

\section{RESULTS AND DISCUSSION}

\section{Yield attributes}

The growth and yield attributes were significantly influenced by sowing dates and varieties (Table 1). The significantly highest effective tillers $\mathrm{m}^{-2}$ were recorded in crop sown on $20^{\text {th }}$ November (285) which was statistically on par with $5^{\text {th }}$ November (275) sown crop and were significantly better than other dates of sowing. Among different varieties, the effective tillers $\mathrm{m}^{-2}$ recorded in 'VL-907' and 'VL-829' were significantly more than 'VL-892' and 'HS-490'. Similarly, numbers of grains spike $^{-1}$ was significantly more in 'VL-907' (43) and VL-829 (39). Maximum 1000-grain weight (46.4 g) was recorded on $20^{\text {th }}$ November sown crop and among varieties VL-907 (45.2 g). The straw yield was also higher under $5^{\text {th }}$ and $20^{\text {th }}$ November (6397 and $6104 \mathrm{kgha}^{-1}$, respectively) sowing environments. The wheat variety 'VL-907' produced highest straw yield $\left(6396 \mathrm{kgha}^{-1}\right)$. The higher yield and yield attributing parameters under early over delayed sowing could be attributed to availability of optimum environmental conditions for growth and development of crop which might have enhanced accumulation of photosynthates from source towards sink.

Table 1: Effect of sowing dates and varieties on yield and yield attributes of wheat (Pooled 2015-16 and 2016-17)

\begin{tabular}{|c|c|c|c|c|c|c|c|}
\hline Treatments & $\begin{array}{l}\text { Grain yield } \\
\qquad\left(\mathrm{kgha}^{-1}\right)\end{array}$ & $\begin{array}{l}\text { Straw yield } \\
\qquad\left(\mathrm{kgha}^{-1}\right)\end{array}$ & $\begin{array}{l}\text { No. of } \\
\text { grains } \\
\text { spike }^{-1}\end{array}$ & $\begin{array}{c}\text { No. of } \\
\text { effective } \\
\text { tillers } \mathrm{m}^{-2}\end{array}$ & $\begin{array}{l}\text { 1000-grain } \\
\text { weight }(\mathrm{g})\end{array}$ & $\begin{array}{l}\text { Length of } \\
\text { spike (cm) }\end{array}$ & $\begin{array}{r}\text { Harvest } \\
\text { index }\end{array}$ \\
\hline \multicolumn{8}{|l|}{ Sowing dates } \\
\hline $20^{\text {th }}$ Oct. & 3449 & 5384 & 38 & 263 & 41.6 & 10.6 & 0.40 \\
\hline $05^{\text {th }}$ Nov. & 3863 & 6104 & 40 & 275 & 42.6 & 10.9 & 0.40 \\
\hline $20^{\text {th }}$ Nov. & 4065 & 6397 & 43 & 285 & 46.4 & 11.6 & 0.39 \\
\hline $05^{\text {th }}$ Dec. & 3276 & 5040 & 37 & 261 & 40.8 & 10.5 & 0.39 \\
\hline $20^{\text {th }}$ Dec. & 3187 & 5054 & 35 & 257 & 38.6 & 10.2 & 0.38 \\
\hline $\operatorname{LSD}(\mathrm{P}=0.05)$ & 130 & 313 & 2 & 6 & 1.8 & 0.3 & NS \\
\hline \multicolumn{8}{|l|}{ Varieties } \\
\hline HS- 490 & 3519 & 5026 & 34 & 264 & 40.9 & 10.5 & 0.41 \\
\hline VL- 829 & 3726 & 6054 & 39 & 272 & 42.1 & 10.8 & 0.38 \\
\hline VL- 892 & 3255 & 4908 & 37 & 259 & 39.7 & 10.5 & 0.40 \\
\hline VL- 907 & 3771 & 6396 & 43 & 278 & 45.2 & 11.1 & 0.37 \\
\hline $\operatorname{LSD}(\mathrm{P}=0.05)$ & 284 & 417 & 3 & 10 & 2.8 & 0.4 & 0.02 \\
\hline
\end{tabular}


Table 2: Interaction effect of treatments on grain yield $\left(\mathrm{kg} \mathrm{ha}^{-1}\right)$

\begin{tabular}{|c|c|c|c|c|c|}
\hline \multirow{2}{*}{ Varieties } & \multicolumn{5}{|c|}{ Dates of sowing } \\
\hline & $20^{\text {th }}$ Oct. & $5^{\text {th }}$ Nov. & $20^{\text {th }}$ Nov. & $5^{\text {th }}$ Dec. & $20^{\text {th }}$ Dec. \\
\hline HS-490 & 3029 & 4046 & 4102 & 3277 & 3143 \\
\hline VL- 829 & 3877 & 3957 & 3876 & 3623 & 3299 \\
\hline VL- 892 & 3066 & 3254 & 4112 & 2957 & 2884 \\
\hline VL- 907 & 3822 & 4196 & 4168 & 3249 & 3421 \\
\hline
\end{tabular}

For comparison of varieties at same date

For comparison of dates at same or different varieties

\section{Grain yield}

A perusal of data in Table 1 revealed that yield under $20^{\text {th }}$ November sowing (4065 $\mathrm{kgha}^{-1}$ ), was closely followed by $5^{\text {th }}$ November sowing (3863 $\left.\mathrm{kgha}^{-1}\right)$ during both the years. The highest yield recorded with $20^{\text {th }}$ November was due to significantly higher effective tillers (285), grains per spike (43) as well as 1000-grain weight (46.4g) while lowest yield (3187 $\left.\mathrm{kgha}^{-1}\right)$ was recorded from last sowing $\left(20^{\text {th }}\right.$ December). Prevailing high temperature during reproductive phase of the crop growth under delayed sowing caused forced maturity of the crop and resulted in lower test weight, less number of filled grains spike ${ }^{-1}$ and ultimately the lower grain yield. Reduced effective tillers, grains spike ${ }^{-1}$ and 1000-grain weight etc. under delayed sowing are responsible for lesser grain yield. The detrimental effect of heat at later stage of crop development in delayed sowing had adverse effect on grain yield (Mishra et al. 2015).

Among the varieties, VL-907 and VL-829 gave significantly highest grain yield (3771 and $3726 \mathrm{~kg} \mathrm{ha}^{-1}$ ) though it was at par with VL-892 (3519 $\left.\mathrm{kgha}^{-1}\right)$. Both years, VL-892 produced lowest grain yield as compared to other varieties. The interaction effect between dates of sowing and wheat varieties was also found to be significant (Table 2). Under timely sowing, VL-907 produced maximum yield (4196 and $4168 \mathrm{kgha}^{-1}$ ). The greater reduction in yield of long season wheat varieties under delayed sowing was because of shorter growing season length. Delayed sowing hasten the crop phenological development, hence the reduced wheat yields (Singh and Pal, 2003).

\section{Growing degree days (GDD)}

The GDD was calculated from complete emergence to physiological maturity. The GDD decreased with delay in sowing during both the years in all growth stages except
130.1

283.9 during physiological maturity. Sowing date strongly influenced the GDD requirement for a particular developmental stage. Analysis of the data (Table 3) confirmed that postponement of sowing date resulted in reduction of GDD requirement. The cumulative GDD $\left(1512.1^{\circ} \mathrm{C}\right.$ day $\left.^{-1}\right)$ was highest in $20^{\text {th }}$ October. There was a progressive decrease in GDD as the sowing date was delayed from $20^{\text {th }}$ October to $20^{\text {th }}$ December at the rate of 0.6 to 7.7 per cent, respectively. The emergence of wheat cultivars was completed approximately at 121-137 degree days. For maturity accumulated GDD was $1512.1^{\circ} \mathrm{C}$ day $^{-1}$ in $20^{\text {th }}$ October, $1502.7^{\circ} \mathrm{C}$ day $^{-1}$ in $5^{\text {th }}$ November and $1394.6^{\circ} \mathrm{C}$ ayy $^{-1}$ in $20^{\text {th }}$ December both years. The decrease in thermal requirements with delay in sowing may possibly be due to low temperature in late sown crop. The reduction in GDD accumulation was due to reduction in number of days taken to attain any phenological stages under water stress conditions, as was also reported by Bist et al. (2019).

\section{Helio thermal unit (HTU)}

Analysis of the data presented in Table (3), revealed that postponement of sowing date decreased the HTU consumption. With delay in sowing HTU decreased at the rate of 1.9 to 6.06 per cent from $20^{\text {th }}$ October to $20^{\text {th }}$ December. VL829 accumulated maximum HTU followed by VL-907, both years. HTU varied from 4182 to 5953 for ear emergence and 9387 to 12189 for physiological maturity of the crop (Table 1). Hundal et al. (1997) also observed that cumulative helio thermal units (HTU) were reduced with delay in sowing after November due to reduction in actual sunshine hours. Conversely, higher HTU accumulation by the earlier sowing dates was due to extended phenophases.

\section{Photo thermal unit (PTU)}

Analysis of the data described that postponement of sowing date resulted in reduction in PTU requirement (Table 
Table 3: Effect of sowing dates and varieties on Agro meteorological indices at different growth stages of wheat (Pooled data 201516 and 2016-17)

\begin{tabular}{|c|c|c|c|c|c|}
\hline Treatments & Complete emergence & Tillering & Flag leaf & Ear emergence & $\begin{array}{c}\text { Physiological } \\
\text { maturity }\end{array}$ \\
\hline \multicolumn{6}{|c|}{ Growing degree day $\left({ }^{\circ} \mathrm{C}\right.$ days) } \\
\hline \multicolumn{6}{|c|}{ Sowing dates } \\
\hline $20^{\text {th }}$ Oct. & 148 & 601 & 858 & 879 & 1512 \\
\hline $05^{\text {th }}$ Nov. & 140 & 491 & 752 & 787 & 1503 \\
\hline $20^{\text {th }}$ Nov. & 143 & 404 & 631 & 722 & 1458 \\
\hline $05^{\text {th }}$ Dec. & 107 & 305 & 593 & 640 & 1372 \\
\hline $20^{\text {th }}$ Dec. & 105 & 288 & 588 & 622 & 1395 \\
\hline \multicolumn{6}{|l|}{ Varieties } \\
\hline HS- 490 & 126 & 416 & 597 & 616 & 1355 \\
\hline VL- 829 & 137 & 434 & 768 & 886 & 1702 \\
\hline VL- 892 & 121 & 400 & 675 & 698 & 1279 \\
\hline VL- 907 & 130 & 420 & 699 & 719 & 1455 \\
\hline \multicolumn{6}{|c|}{ Helio thermal units $\left({ }^{\circ} \mathrm{C}\right.$ day hour) } \\
\hline \multicolumn{6}{|c|}{ Sowing dates } \\
\hline $20^{\text {th }}$ Oct. & 1232 & 4521 & 6229 & 6338 & 10627 \\
\hline $05^{\text {th }}$ Nov. & 1021 & 3526 & 5088 & 5358 & 10421 \\
\hline $20^{\text {th }}$ Nov. & 998 & 2782 & 4166 & 4723 & 10071 \\
\hline $05^{\text {th }}$ Dec. & 705 & 2035 & 3830 & 4156 & 9624 \\
\hline $20^{\text {th }}$ Dec. & 790 & 1775 & 3840 & 4078 & 9982 \\
\hline \multicolumn{6}{|l|}{ Varieties } \\
\hline HS- 490 & 930 & 2930 & 4034 & 4182 & 9387 \\
\hline VL- 829 & 1013 & 3018 & 5163 & 5953 & 12190 \\
\hline VL- 892 & 895 & 2808 & 4596 & 4742 & 8789 \\
\hline VL- 907 & 958 & 2954 & 4730 & 4846 & 10215 \\
\hline \multicolumn{6}{|c|}{ Photo thermal units $\left({ }^{\circ} \mathrm{C}\right.$ day hour) } \\
\hline \multicolumn{6}{|c|}{ Sowing dates } \\
\hline $20^{\text {th }}$ Oct. & 1544 & 6130 & 8806 & 9048 & 17099 \\
\hline $05^{\text {th }}$ Nov. & 1420 & 4975 & 7779 & 8207 & 17671 \\
\hline $20^{\text {th }}$ Nov. & 1441 & 4109 & 6623 & 7719 & 17666 \\
\hline $05^{\text {th }}$ Dec. & 1091 & 3138 & 6486 & 7073 & 17056 \\
\hline $20^{\text {th }}$ Dec. & 1077 & 3046 & 6729 & 7167 & 17793 \\
\hline \multicolumn{6}{|l|}{ Varieties } \\
\hline HS- 490 & 1290 & 4263 & 6217 & 6456 & 16173 \\
\hline VL- 829 & 1398 & 4459 & 8331 & 9788 & 20985 \\
\hline VL- 892 & 1238 & 4091 & 7150 & 7457 & 15116 \\
\hline VL- 907 & 1331 & 4304 & 7441 & 7670 & 17554 \\
\hline
\end{tabular}

3). The trends of PTU were similar as HTU and GDD for all varieties and sowing environments. A gradual decrease in PTU was noticed with delay in sowing of wheat from $20^{\text {th }}$ October to $20^{\text {th }}$ December. The maximum PTU accumulation $\left({ }^{\circ} \mathrm{C}\right.$ day hour) for attaining maturity was 17793 in $20^{\text {th }}$ December at par $5^{\text {th }}$ November (17671) and $20^{\text {th }}$ November (17666) least in $5^{\text {th }}$ December (17056). VL-829 being a long duration variety accumulateshighest PTU among the varieties.

\section{Heat use efficiency (HUE)}

Heat use efficiency (HUE), heliothermal use efficiency (HTUE) and photothermal use efficiency (PTUE) determine the ability of a plant to convert per unit available energy into the economic product. The data presented in Table 4 revealed that HUE, HTUE and PTU were higher in $20^{\text {th }}$ November followed by $5^{\text {th }}$ November sowing. HUE values varied from 2.31 to 2.86 during sowing windows from $20^{\text {th }}$ October to $20^{\text {th }}$ 
Table 4: Effect of treatments on heat use efficiencies, helio thermal use efficiency and photo thermal use efficiency (Pooled 201516 and 2016-17)

\begin{tabular}{cccc}
\hline Treatments & HUE & HTUE & PTUE \\
\hline Sowing dates & 2.31 & 0.33 & 0.21 \\
$20^{\text {th }}$ Oct. & 2.62 & 0.38 & 0.22 \\
$05^{\text {th }}$ Nov. & 2.86 & 0.42 & 0.24 \\
$20^{\text {th }}$ Nov. & 2.41 & 0.35 & 0.19 \\
$05^{\text {th }}$ Dec. & 2.31 & 0.32 & 0.18 \\
$20^{\text {th }}$ Dec. & 0.15 & 0.02 & 0.01 \\
LSD (P=0.05) & & & \\
Varieties & 2.63 & 0.38 & 0.22 \\
HS- 490 & 2.20 & 0.31 & 0.18 \\
VL- 829 & 2.55 & 0.37 & 0.22 \\
VL- 892 & 2.62 & 0.38 & 0.22 \\
VL- 907 & 0.22 & 0.04 & 0.02 \\
LSD (P=0.05) & & & \\
\hline
\end{tabular}

December. Both years, the maximum $\operatorname{HUE}\left(2.86 \mathrm{~kg} /{ }^{\circ} \mathrm{C}\right.$ days $)$, $\operatorname{HTUE}\left(0.42 \mathrm{~kg} /{ }^{\circ} \mathrm{C}\right.$ day hour $)$ and PTUE $\left(0.24 \mathrm{~kg} /{ }^{\circ} \mathrm{C}\right.$ day hour $)$ were found in $20^{\text {th }}$ November (Table 4$)$. Whereas, minimum HUE and HTUE, PTUE were recorded in $20^{\text {th }}$ December (2.31, 0.32 and 0.18 , respectively). The efficiencies were higher in November sowing dates due to higher yield during November sowing as compared to the delayed sowings. Sattar et al. (2015) also reported higher heat use efficiency, while as Girijesh et al. (2011) reported higher helio thermal use efficiency within optimum sowing window.

\section{CONCLUSION}

The crop sown on $20^{\text {th }}$ October could took maximum calendar days hence, higher growing degree days, photothermal units and helio-thermal units for all the stages which were considerably reduced with subsequent delay in sowing. Thus, wheat crop sown on $20^{\text {th }}$ November recorded the highest grain yield closely followed by $5^{\text {th }}$ November sown crop. Among the varieties the timely sown wheat varieties 'VL-829' acquired maximum thermal units and produced maximum yield because of longer duration. HS-490 and VL-907 have potential to efficiently convert the heat units into the economic yield and biomass.

\section{REFERENCES}

Bishnoi, O.P., Singh, S. and Niwas, R. (1996). Testing and validation of CERES-wheat model in different environments. Agricultural Science Digest, Karnal, 16 (2): 101-104.

Bist, H., Singh, D.K., Shaloo, Mishra, A.K., Sarangi, A., Prajapati, V.K., Singh, M. and Krishnan, P. (2019). Heat unit requirement of wheat under different thermal and moisture regimes. J. Agrometeorol., 21(1):36-41.

FAO. (2017). Food and Agriculture Organization of the United Nations. http://FAOSTAT.fao.org $\left[18^{\text {th }} \mathrm{Feb}\right.$, 2019]

Girijesh, G.K., Kumara, A.S., Sridhara, S., Kumar, D.M., Vageesh, T.S. and Nataraju, S.P. (2011). Heat use efficiency and helio-thermal units for maize varieties as influenced by dates of sowing under southern transitional zone of Karnataka state. International J. Sci. Nature, 2:529-33.

Hari Ram, Singh, G., Mavi, G.S. and Sahu, V.S. (2012). Accumulated heat unit requirement and yield of irrigated wheat wheat (Tritium aestivum L.) varieties under different crop growing environment in central Punjab. J. Agrometeorol., 14(2): 147-153.

Hundal, S.S., Singh, R. and Dhaliwal, L.K. (1997). Agroclimatic indices for predicting phenology of wheat (Triticum aestivum) in Punjab. Indian J. Agric. Sci., 67(6): 265-268 
Mishra, S.K., Shekh, A.M., V. Pandey, Yadav, S.B. and Patel, H.R. (2015). Sensitivity analysis of four wheat cultivars to varying photoperiod and temperature at different phonological stages using WOFOST model. J. Agrometeorol., 17(1): 74-79.

Sattar, A., Iqbal, M.M., Areeb, A., Ahmed, Z., Irfan, M., Shabbir, R.N., Aisha, G. and Hussian, S. (2015). Variety variation in wheat for phenology and accumulative heat unit under different sowing times. $J$.
Environ. Agric. Sci., 2:1-8.

Singh, S. and Pal, M. (2003). Growth, yield and phonological response of wheat cultivars to delayed sowing. Indian Journal of Plant Physiology, 8: 277-286.

Wardlaw, I.F. and Wringley, C.W. (1994). Heat tolerance in temperate cereals. An Overview. Australian Journal of Plant Physiology, 21: 695-703. 